\title{
SYNTHESIS, THERMAL BEHAVIOR AND SPECTROSCOPIC INVESTIGATIONS OF METAL COMPLEXES WITH $N$-MODIFIED GLYCINE AS LIGAND
}

\author{
CARMEN SACALIS ${ }^{\mathrm{a}}$, FIRUTA GOGA ${ }^{\mathrm{a}}$, LEONTIN DAVID ${ }^{\mathrm{b}}$
}

\begin{abstract}
The $\mathrm{Cu}(\mathrm{II}), \mathrm{Co}(\mathrm{II})$ and $\mathrm{Ni}(\mathrm{II})$ complexes with $\mathrm{N}$-modified glycine derived from $p$-nitrophenylserinol were synthesized and characterized by their spectral and thermal properties. The thermal stability of the ligand and synthesized complexes was discussed in the $20-700^{\circ} \mathrm{C}$ temperature range. The results indicate that the organic compound acts as a bidentate ligand, its coordination involving the carboxylate oxygen and the nitrogen atom belonging to the amino group of the glycine fragment. All complexes correspond to the molar ratio $\mathrm{M}: \mathrm{L}: \mathrm{H}_{2} \mathrm{O}=1: 2: 2$. The shape of the ESR spectra at room temperature and the principal values of the $\mathrm{g}$ tensor suggest a pseudotetrahedral local symmetry around the metal ions.
\end{abstract}

Keywords: glycine, metal complexes, thermal behavior, spectroscopic studies

\section{INTRODUCTION}

Amino acids play a crucial role in intra-cellular process of living organism. A lot of biochemical processes involve metal ions. The metal-amino acid interaction can be treated as a model of metal-protein system. The study of model species such as the simple amino acids can assist in the interpretation of more complex system. Complexes of transition metals with amino acids like glycine, very small biomolecules, have received much attention because they proved biological activity such as antibacterial, antimicrobial or antifungal activities [1-4].

\footnotetext{
a Babeş-Bolyai University, Faculty of Chemistry and Chemical Engineering, 11 Arany Janos str., RO-400028, Cluj-Napoca, Romania

b Babeş-Bolyai University, Faculty of Physics, 1 Mihail Kogalniceanu str., RO-400084, ClujNapoca, Romania

*Corresponding author: cbatiu@chem.ubbcluj.ro
} 
In-vitro studies of coordination complexes of $\mathrm{Mn}(\mathrm{II}), \mathrm{Co}(\mathrm{II}), \mathrm{Ni}(\mathrm{II}), \mathrm{Cu}(\mathrm{II})$, $\mathrm{Cd}$ (II) with glycine and phenylalanine indicated antimicrobial activity for Grampositive bacteria such as Bacillus subtilis and Staphylococcus aureus, and Gram-negative such as E.coli, Pseudomonas aeruginosa, Proteus vulgaris and Candida albicans [3].

Recently studies of copper (II) complex with glycine report that is a very good antifungal agent for Phytophthora Capsici, an important pathogenic species which causes serious disease on plants [5].

Other research indicates that $\mathrm{N}$-substituted glycine and their transition metal complexes act as hydrogen buffers in biological reactions [6]. $\mathrm{N}$-modified glycines have a lot of applications in biomedicine as analogue of anticonvulsant and antiepileptic agent Milacemide, as building-units for $N$-backbone cyclic peptides, even in the detergent industry [7-9].

The ligand $\mathbf{L}=2-[(1 S, 2 S)-1,3-$ dihydroxy-1-(4-nitrophenyl)propan-2-ylamino]acetic acid (Figure 1), was obtained by a literature procedure by treatment of $p$-nitrophenylserinol with the monochloroacetic acid/ $\mathrm{Na}_{2} \mathrm{CO}_{3}$ system and investigated by spectroscopic methods [10].

Taking into account the important biochemical applications of $\mathrm{N}$-modified glycine, we report the synthesis, the spectroscopic and thermogravimetric investigation of the ligand $\mathbf{L}$ and its transition metal complexes with $\mathrm{Cu}(\mathrm{II})$, $\mathrm{Co}(\mathrm{II})$ and $\mathrm{Ni}(\mathrm{II})$.<smiles>O=C(O)CNC(CO)C(O)c1ccc([N+](=O)[O-])cc1</smiles>

Figure 1. Structure formula of ligand $\mathbf{L}: 2-[(1 S, 2 S)-1,3-$ dihydroxy-1-(4nitrophenyl)propan-2-yl-amino]acetic acid

\section{RESULTS AND DISCUSSION}

\section{The structure of the metal complexes}

The complexation reaction of $\mathrm{Cu}(\mathrm{II}), \mathrm{Co}(\mathrm{II})$ and $\mathrm{Ni}(\mathrm{II})$ salts with the ligand solution in each case yields a solid product. All complexes are colored, microcrystalline and stable at room temperature. They are also insoluble in water, non-polar organic solvents (diethyl ether, $\mathrm{CHCl}_{3}, \mathrm{CCl}_{4}$, benzene and toluene) but soluble in methanol or DMSO. Higher melting points of these products as well their different colors when compared to that of the ligand $\mathbf{L}$, indicate the formation of metal complexes. 
The elemental analysis data (Table 1) and thermal analysis data (Table 2) indicate the molar ratio Metal : Ligand : $\mathrm{H}_{2} \mathrm{O}=1: 2: 2$., for each complex.

The UV-VIS spectra in $\mathrm{CH}_{3} \mathrm{OH}_{\mathrm{abs}}$ for the complexes (1- $\left.\underline{\mathbf{3}}\right)$ indicate a slight bathochromic shift by 4-6 $\mathrm{nm}$, but a considerable hyperchromic increase effect of absorbance comparative to the spectrum of the initial ligand (L), like the other similar complexes $[4,11,12]$. The shift of $n \rightarrow \pi^{*}$ characteristic band in the UV spectra attributed to the $\mathrm{C}=\mathrm{O}$ bond $(26 \overrightarrow{2} .4 \mathrm{~nm}$ for the ligand; lit. for glycine $270 \mathrm{~nm}$ [4] ) is due to the involving of the nonbonding electron pairs of the oxygen in the metal-ligand bond formation. The study shows that the absorption spectra of the obtained complexes are determined by the coordinated organic ligand provides from amino acids what is typical for transitional metal complexes [13-15].

Another proof for the complexation process is the HRMS spectrum for the ligand and its metal complexes (Figure 2a-c). The M+1 peak supports the complexation idea with the transition metal ions, for each of them.

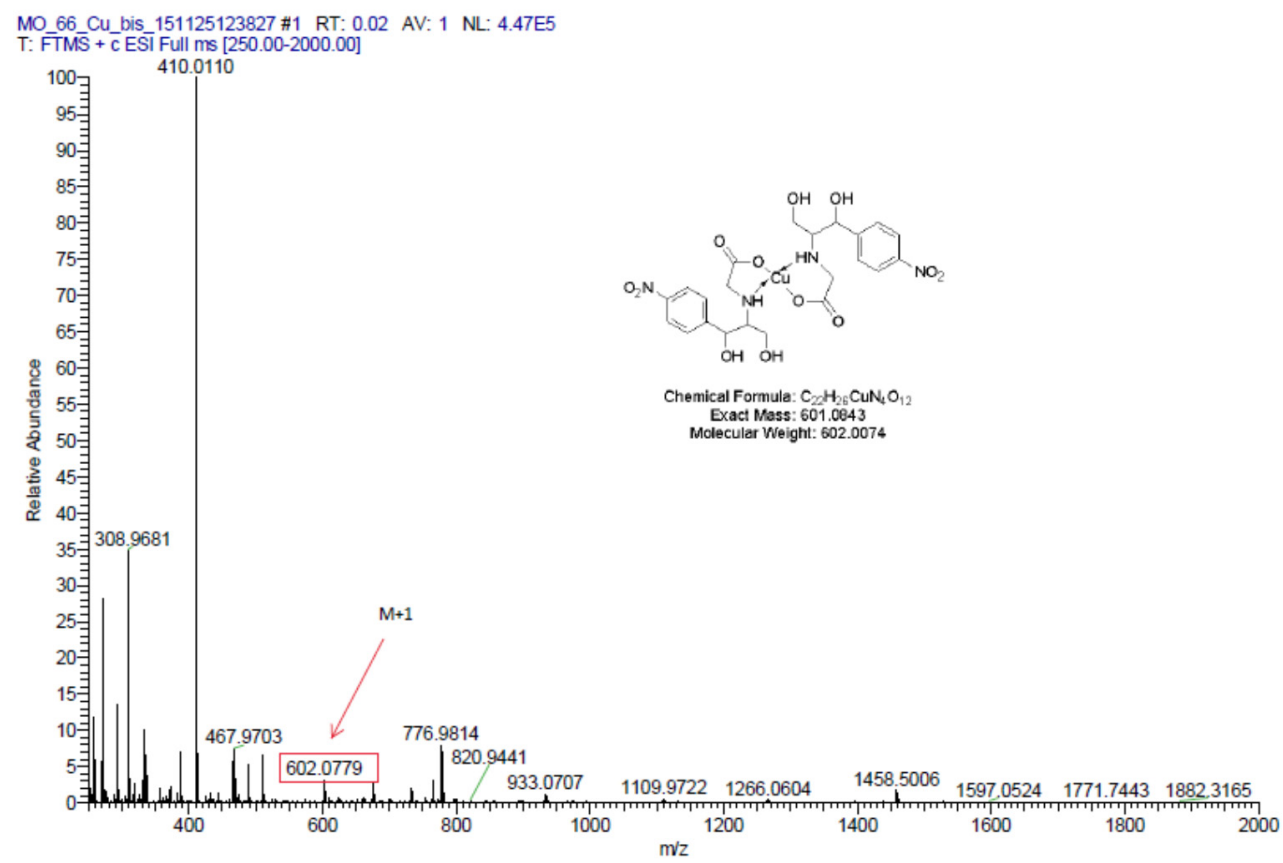

Figure 2a. HRMS spectrum (ESI) of copper complex 


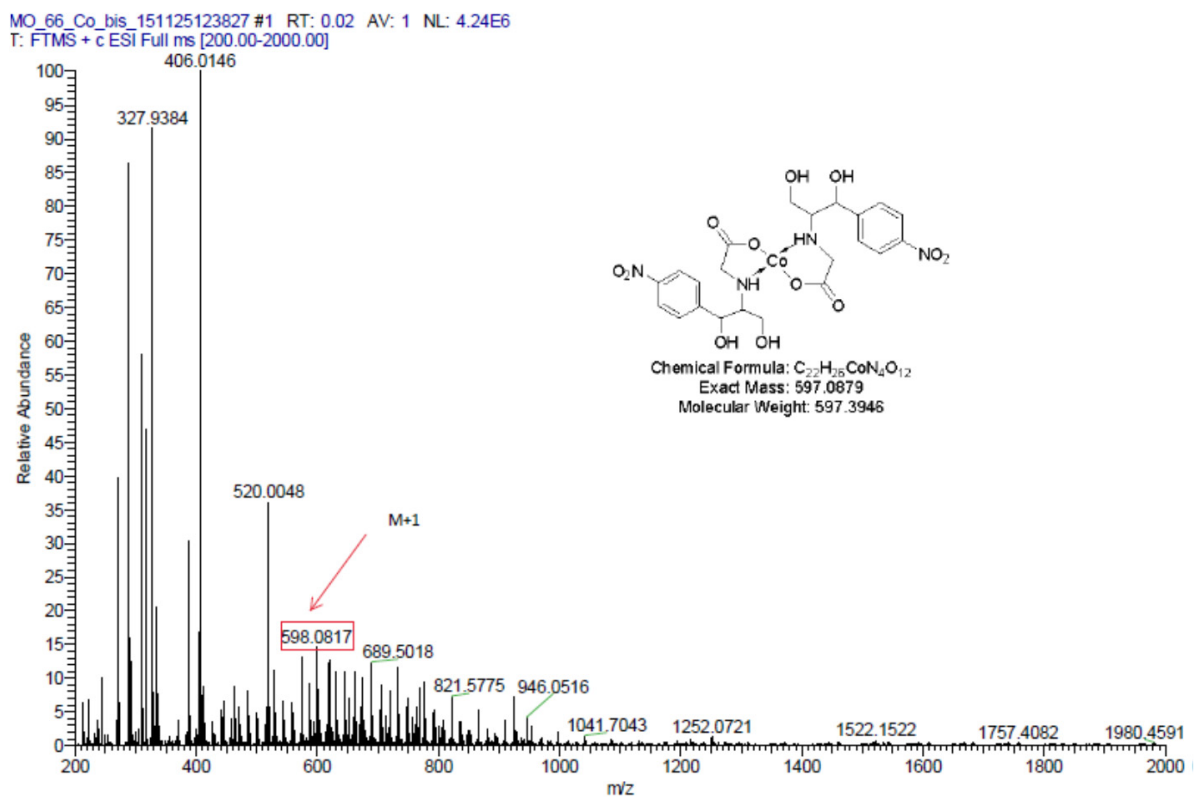

Figure 2b. HRMS spectrum (ESI) of cobalt complex

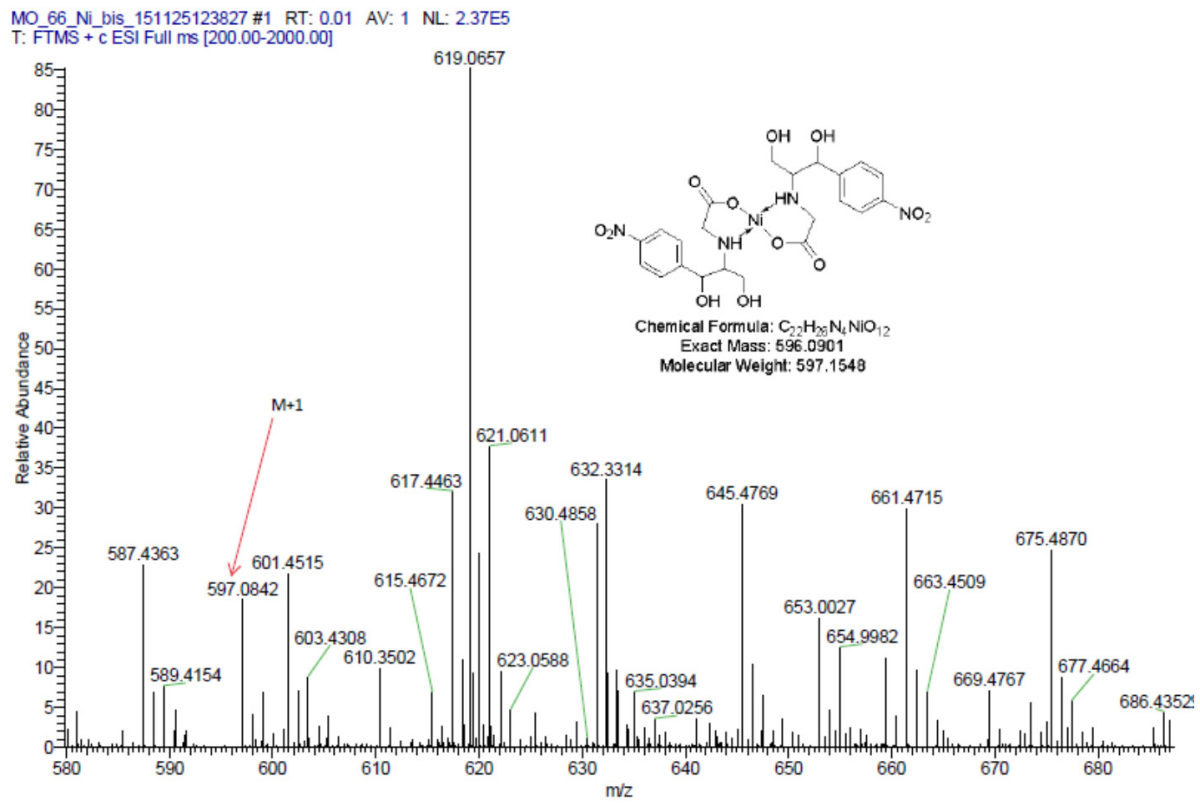

Figure 2c. HRMS spectrum (ESI) of nickel complex 
SYNTHESIS, THERMAL BEHAVIOR AND SPECTROSCOPIC INVESTIGATIONS OF METAL ...

Table 1. Physico-chemical and elemental analysis data of the ligand $\mathbf{L}$ and its metal complexes (1- $\underline{\mathbf{3}})$

\begin{tabular}{|c|c|c|c|c|c|}
\hline \multicolumn{2}{|c|}{ Compound } & $\begin{array}{c}\mathrm{C}_{11} \mathrm{H}_{14} \mathrm{~N}_{2} \mathrm{O}_{6} \\
(\mathrm{~L})\end{array}$ & $\begin{array}{c}\mathrm{C}_{22} \mathrm{H}_{30} \mathrm{CuN}_{4} \mathrm{O}_{14} \\
(\mathbf{1})\end{array}$ & $\begin{array}{c}\mathrm{C}_{22} \mathrm{H}_{30} \mathrm{CoN}_{4} \mathrm{O}_{14} \\
(\underline{2})\end{array}$ & $\begin{array}{c}\mathrm{C}_{22} \mathrm{H}_{30} \mathrm{NiN}_{4} \mathrm{O}_{14} \\
(\underline{\mathbf{3}})\end{array}$ \\
\hline \multicolumn{2}{|c|}{ Molec.Weight } & 270.2387 & 638.0380 & 633.4252 & 633.1854 \\
\hline \multicolumn{2}{|c|}{ Yield [\%] } & 58 & 94 & 79 & 40 \\
\hline \multicolumn{2}{|c|}{ Colour } & $\begin{array}{c}\text { yellow-pale } \\
\text { powder }\end{array}$ & $\begin{array}{c}\text { green-turquoise } \\
\text { powder }\end{array}$ & $\begin{array}{c}\text { ecru } \\
\text { powder }\end{array}$ & $\begin{array}{l}\text { greenish- } \\
\text { yellow powder }\end{array}$ \\
\hline \multicolumn{2}{|c|}{$\begin{array}{c}{[\alpha]_{546^{25}}(\mathrm{c}=0.5} \\
\left.\mathrm{CH}_{3} \mathrm{OH}\right)\end{array}$} & +52.42 & -53.13 & -92.88 & -126.51 \\
\hline \multicolumn{2}{|c|}{$\begin{array}{c}\text { Melting point } \\
{\left[{ }^{\circ} \mathrm{C}\right]}\end{array}$} & $213-4$ & 233-4 & $285-6$ & $254-5$ \\
\hline \multirow{3}{*}{$\begin{array}{c}\text { Visible } \\
\text { absorption } \\
\text { spectrum } \\
\text { data, in } \\
\mathrm{CH}_{3} \mathrm{OH} \text { abs }\end{array}$} & $\begin{array}{l}\Lambda_{\max } \\
(\mathrm{nm})\end{array}$ & 262.4 & 266.9 & 268.1 & 267.5 \\
\hline & $\varepsilon$ & 963 & 3854 & 3383 & 3420 \\
\hline & $A$ & 0.499155 & 1.429968 & 0.962325 & 1.088011 \\
\hline \multirow{3}{*}{$\begin{array}{c}\text { Elemental } \\
\text { analysis } \\
\text { data [\%] } \\
\text { found. } \\
\text { (calcd.) }\end{array}$} & $\mathrm{C}$ & $\begin{array}{c}48.57 \\
(48.89) \\
\end{array}$ & $\begin{array}{c}40.66 \\
(41.41) \\
\end{array}$ & $\begin{array}{c}40.61 \\
(41.72) \\
\end{array}$ & $\begin{array}{c}41.67 \\
(41.73) \\
\end{array}$ \\
\hline & $\mathrm{H}$ & $\begin{array}{c}4.90 \\
(5.22)\end{array}$ & $\begin{array}{c}4.37 \\
(4.74)\end{array}$ & $\begin{array}{c}4.32 \\
(4.77)\end{array}$ & $\begin{array}{c}4.39 \\
(4.78)\end{array}$ \\
\hline & $\mathrm{N}$ & $\begin{array}{c}10.36 \\
(10.37)\end{array}$ & $\begin{array}{c}8.77 \\
(8.78)\end{array}$ & $\begin{array}{c}8.61 \\
(8.85)\end{array}$ & $\begin{array}{c}8.84 \\
(8.85)\end{array}$ \\
\hline
\end{tabular}

\section{Thermal investigation}

The thermal behaviors of the ligand (L) and its metal complexes (1-3) are summarized in Table 2 and Figure 3a-d.

The thermogravimetric analysis indicated that the ligand $(\mathbf{L})$ is anhydrous and the decomposition involved three steps. In the temperature range 30$194^{\circ} \mathrm{C}$ a small endothermic peak at $56^{\circ} \mathrm{C}$ with a mass loss of $1.12 \%$ represented the loss of residual water present in the pores. This phenomenon could be explained by the general synthesis of the ligand from aqueous solution [10].

The first decomposition step occurred in the temperature range 194$240^{\circ} \mathrm{C}$ and it has been accompanied by an endo peak at $233^{\circ} \mathrm{C}$. This process could be assigned to the $\mathrm{NO}_{2}$ group cleavage from the aromatic ring accompanied by the melting, according to the literature data for other nitro-derivatives analogous $[10,16-18]$. In the second stage of decomposition of ligand two exothermic peaks at $248^{\circ} \mathrm{C}$, respectively at $347^{\circ} \mathrm{C}$, indicated the cleavage of glycine rest accompanied by oxidation processes. The last step occurred in the temperature range $452-700^{\circ} \mathrm{C}$ and it has been accompanied by two strongly exothermic effects at $580^{\circ} \mathrm{C}$ and at $616^{\circ} \mathrm{C}$ which indicated the pyrolysis of organic rest. The theoretic weight loss (50.05\%) and the experimental one (49.55\%) agree with the loss of remaining organic rest. At $637^{\circ} \mathrm{C}$ the ligand was completely pyrolized. 


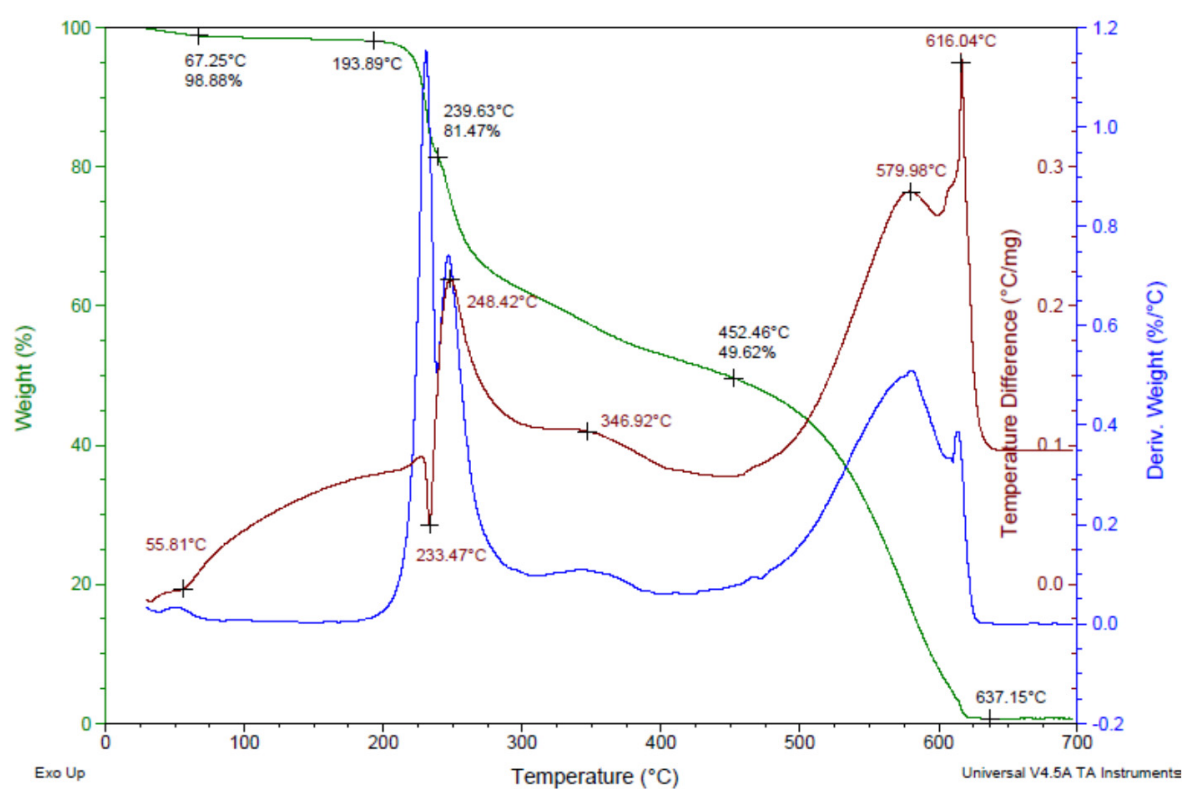

Figure 3a. TG-DTG-DTA diagram for the ligand $L$

The aim of the thermal analysis of the metal complexes is to obtain information concerning their thermal stability of these and to decide whether the water molecules are inside or outside the coordination sphere.

The decomposition of each metal complex occurs in two or three steps. First step corresponds to the loss of water molecules. After that, partial decomposition and then total decomposition of organic ligands takes place. The final products of the pyrolysis are metal oxides.

Thermal decomposition of the copper complex (1) was achieved in three stages. These mass losses occur in the temperature range of $30-192^{\circ} \mathrm{C}$, $192-250^{\circ} \mathrm{C}$ and $250-700^{\circ} \mathrm{C}$. The first step with an estimated mass loss of $6.40 \%$ (calculated $5.64 \%$ ) could be assigned to loss of 2 moles of hydration water. The second stage of decomposition was observed in the $192-250^{\circ} \mathrm{C}$ with a mass loss of $40.93 \%$ (calculated $38.88 \%$ ) and corresponds to a glycine rest and nitro-groups loss. The third-stage decomposition takes place at $250-700^{\circ} \mathrm{C}$ with two exothermic peaks at $325^{\circ} \mathrm{C}$, respectively $352^{\circ} \mathrm{C}$ and corresponds to the pyrolysis of organic rest. The final product is $\mathrm{CuO}$ residue. 
SYNTHESIS, THERMAL BEHAVIOR AND SPECTROSCOPIC INVESTIGATIONS OF METAL ...

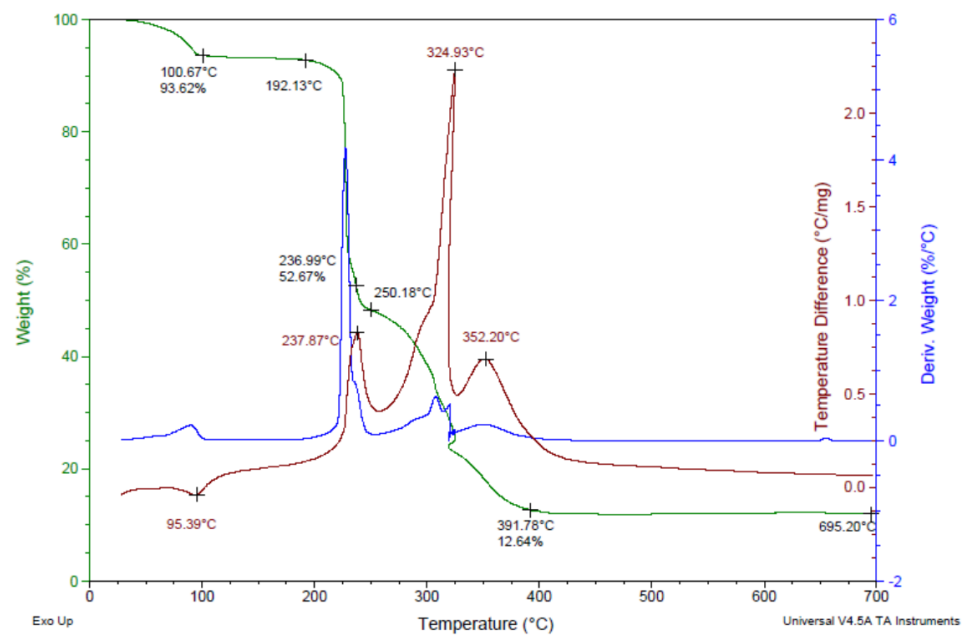

Figure 3b. TG-DTG-DTA diagram for copper complex (1)

For the cobalt complex (2), the first stage decomposition starts in the range $30-211^{\circ} \mathrm{C}$, with an endothermic peak at $87^{\circ} \mathrm{C}$ and a mass loss of $6.26 \%$ which correspond to the loss of two moles of hydration water (calculated $5.69 \%$ ). A strong exothermic effect (see Figure 3c), was assigned to the total pyrolysis of metal complex. The recorded mass loss of $81.34 \%$ is in good agreement to the calculated data $(81.76 \%)$. Finally, the metal oxide remains in the crucible.

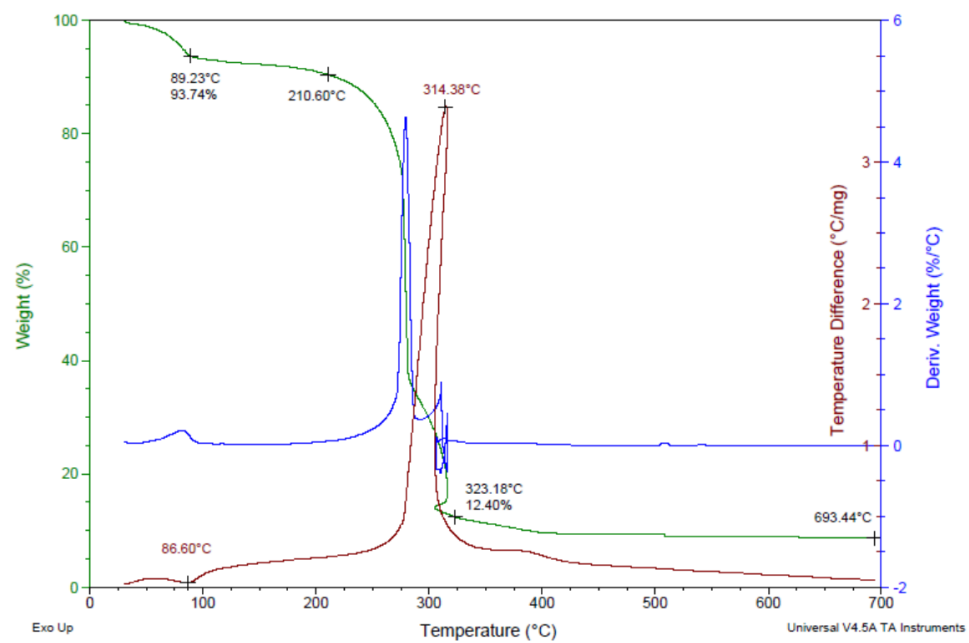

Figure 3c. TG-DTG-DTA diagram for cobalt complex (2) 


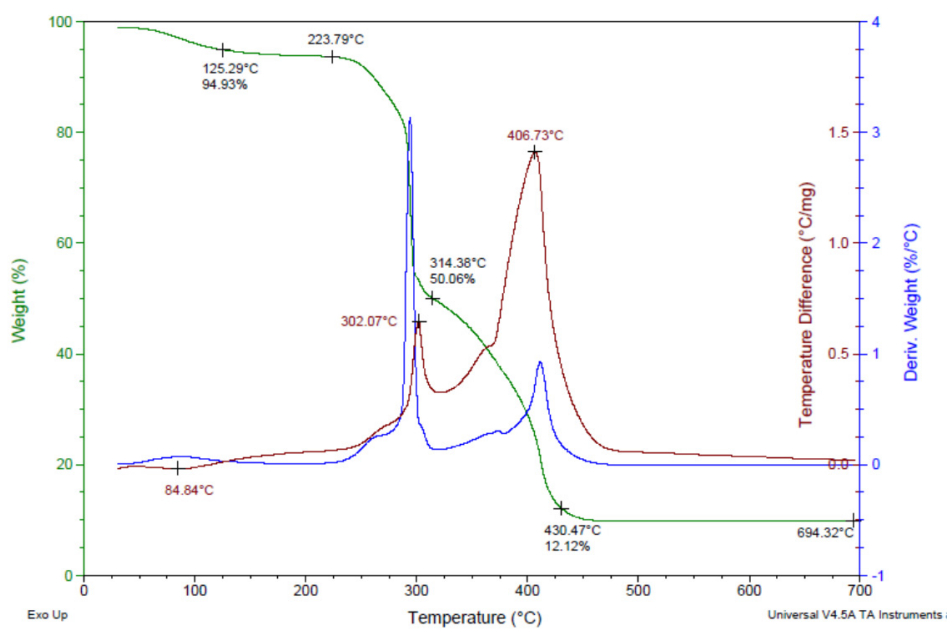

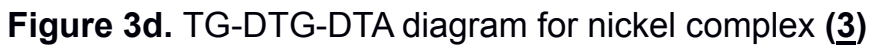

Table 2. Thermal analysis data of the ligand $L$ and its metal complexes (1- $\underline{-})$ in air atmosphere $\left(10^{\circ} \mathrm{C} / \mathrm{min}\right)$

\begin{tabular}{|c|c|c|c|c|c|c|c|}
\hline Compound & Heat & & eratur & $\left.{ }^{0} \mathrm{C}\right)$ & Mass & s (\%) & Assignment \\
\hline & $\begin{array}{l}\text { effect on } \\
\text { DTA }\end{array}$ & $T_{i}$ & & & Cal & Exp. & \\
\hline $\mathrm{L}$ & Endo & 30 & 56 & 194 & - & 1.12 & -residual water present inside \\
\hline & Endo & 194 & 233 & 240 & 17.02 & 17.41 & -melting accompanied by $\mathrm{NO}_{2}$ \\
\hline & $\begin{array}{l}\text { Exo } \\
\text { Exo }\end{array}$ & 240 & $\begin{array}{l}248 \\
347\end{array}$ & 452 & 33.03 & 31.85 & -glycine rest $\left(\mathrm{C}_{2} \mathrm{H}_{4} \mathrm{O}_{2} \mathrm{~N}\right)$ and \\
\hline & $\begin{array}{l}\text { Exo } \\
\text { Exo }\end{array}$ & 452 & $\begin{array}{l}580 \\
616\end{array}$ & 700 & 50.05 & 49.55 & -pyrolysis of organic rest \\
\hline $\begin{array}{c}\mathrm{Cu}(\mathrm{L}) \cdot 2 \mathrm{H}_{2} \mathrm{O} \\
\text { (1) }\end{array}$ & Endo & 30 & 95 & 192 & 5.64 & 6.40 & $\begin{array}{l}-2 \text { moles of hydrating water and } \\
\text { probably residual water inside } \\
\text { pores }\end{array}$ \\
\hline & Exo & 192 & 238 & 250 & 39.88 & 40.93 & -2 moles of glycine rest and $\mathrm{NO}_{2}$ \\
\hline & Exo & 250 & $\begin{array}{l}325 \\
352\end{array}$ & 700 & 41.27 & 40.49 & -pyrolysis of organic rest \\
\hline & & & & & 13.21 & 12.64 & CuO residue \\
\hline $\mathrm{Co}(\mathrm{L}) \cdot 2 \mathrm{H}_{2} \mathrm{O}$ & Endo & 30 & 87 & 211 & 5.69 & 6.26 & -2 moles of hydrating water \\
\hline & Exo & 211 & 314 & 323 & 81.76 & 81.34 & $\begin{array}{l}\text {-quickly cleavage and pyrolysis } \\
\text { of organic rest }\end{array}$ \\
\hline & & & & & 12.54 & 12.40 & $\mathrm{CoO}$ residue \\
\hline $\mathrm{Ni}(\mathrm{L}) \cdot 2 \mathrm{H}_{2} \mathrm{O}$ & Endo & 30 & 85 & 224 & 5.69 & 5.07 & -2 moles of hydrating water \\
\hline ( & Exo & 234 & 302 & 314 & 41.28 & 42.76 & $\begin{array}{l}-2 \text { moles of glycine rest and } \mathrm{NO}_{2} \\
\text { groups }\left(2 \mathrm{C}_{4} \mathrm{H}_{8} \mathrm{O}_{8} \mathrm{~N}_{4}\right)\end{array}$ \\
\hline & Exo & 314 & 407 & 430 & $\begin{array}{l}40.39 \\
12.54\end{array}$ & $\begin{array}{l}38.89 \\
12.12\end{array}$ & $\begin{array}{l}\text {-pyrolysis of organic rest } \\
\text { NiO residue }\end{array}$ \\
\hline
\end{tabular}

$\mathrm{T}_{\mathrm{i}}=$ initial temperature, $\mathrm{T}_{\max }=$ maximum temperature, $\mathrm{T}_{\mathrm{f}}=$ final temperature 
The TG data showed that the nickel complex starts its decomposition at $85^{\circ} \mathrm{C}$. The first decomposition strep starts with dehydration and corresponds to loss of two moles of water. Organic ligand molecule is stable until $302^{\circ} \mathrm{C}$. The second ant third stages correspond to the organic ligand decomposition. The final product is $\mathrm{NiO}(12.12 \%$ exp., calcd. $12.54 \%)$.

\section{ESR spectra}

Powder ESR spectra of metallic complexes at room temperature (Figure 4) are typical for pseudotetrahedral monomeric species. The principal values of the $\mathrm{g}$ tensor $\mathrm{g}_{\|}=2.560$ and $\mathrm{g}_{\perp}=2.071$ for $\mathrm{Cu}$ complex, correspond to a $\mathrm{CuN}_{2} \mathrm{O}_{2}$ cromophore [19]. Similar value for Co complex $\left(\mathrm{g}_{\|}=2.0719\right.$, $\left.g_{\perp}=2.019\right)$ and for Ni complex $\left(g_{\|}=2.065, g_{\perp}=2.071\right)$ suggest the same local symmetry around the metal ions.

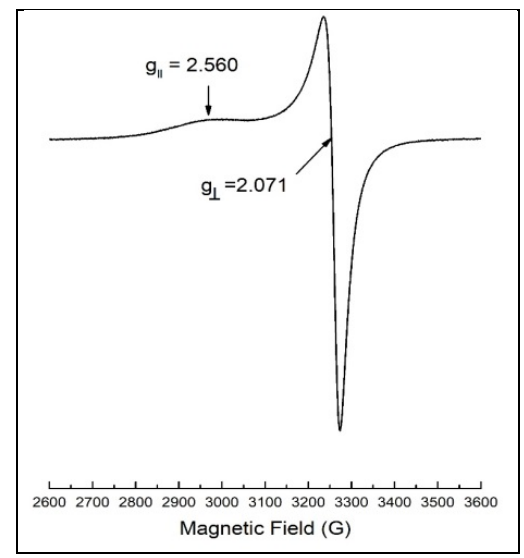

Figure 4. Powder ESR spectrum of copper complex at room temperature

\section{CONCLUSIONS}

Three new transition metal complexes (1- $\underline{\mathbf{3}})$ of an $\mathrm{N}$-modified glycine (L) as ligand were synthesized and analyzed by elemental, thermogravimetric analysis and spectral studies. The results are in good agreement with the corresponding formulae: $\mathrm{C}_{11} \mathrm{H}_{14} \mathrm{~N}_{2} \mathrm{O}_{6}(\mathrm{~L}),\left[\mathrm{Cu}\left(\mathrm{C}_{11} \mathrm{H}_{13} \mathrm{~N}_{2} \mathrm{O}_{6}\right)_{2}\right] \cdot 2 \mathrm{H}_{2} \mathrm{O}$ (1), $\left[\mathrm{Co}\left(\mathrm{C}_{11} \mathrm{H}_{13} \mathrm{~N}_{2} \mathrm{O}_{6}\right)_{2}\right] \cdot 2 \mathrm{H}_{2} \mathrm{O}$ (2), respectively $\left[\mathrm{Ni}\left(\mathrm{C}_{11} \mathrm{H}_{13} \mathrm{~N}_{2} \mathrm{O}_{6}\right)_{2}\right] \cdot 2 \mathrm{H}_{2} \mathrm{O}(\underline{\mathbf{3}})$. The ligand coordinated the metal ions through $\mathrm{N}$ and $\mathrm{O}$ donor atoms. The $\mathrm{ESR}$ spectra at room temperature indicated pseudotetrahedral local symmetry around the metal ions. 
During heating in air atmosphere, both the ligand and its metal complexes decompose in multistage. Some stages of pyrolysis are weakly separated one from another. Decomposition of investigated compounds begins with total loss of water, then with gradual destruction of ligand. The final products of pyrolysis are the metal oxides from each of transition metal complexes.

Mass spectra data indicated the $\mathrm{M}+1$ peak corresponding for each of investigated compounds.

\section{EXPERIMENTAL SECTION}

\section{Materials and instrumentation}

All reagents and chemicals were purchased from commercial sources and used as received. Elemental analyses were determined on Thermo Scientific Flash EA 1112 Elemental Analyzer. Melting points were measured on an ELECTROTHERMAL ${ }^{\circledR}$ instrument and and were not corrected. The electronic absorption spectra were performed on CECIL CE 9500 spectrophotometer. Specific rotations were estimated on a Polamat A Karl Zeis Jena photopolarimeter. GC-MS spectra were recorded on a Gas Chromatograph with Mass Spectrometer Shimadzu ${ }^{\circledR}$ QP 2010 PLUS. Mass spectra were carried out on a LTQ ORBITRAP ${ }^{\circledR}$ $\mathrm{XL}$ (Thermo Scientific) instrument which was externally calibrated using the manufacturer's APCl or ESI(+) calibration mix. The samples were introduced into the spectrometer by direct infusion. The EPR measurements were carried out on a Bruker Biospin EMXmicro spectrometer operating at X-band $(9-10 \mathrm{GHz})$ with continuous wave at $X$-band $(\approx 9 \mathrm{GHz})$. The spectra were recorded at room temperature with a microwave frequency of $9.4353 \mathrm{GHz}$, microwave power of $2 \mathrm{~mW}$, modulation frequency of $100 \mathrm{kHz}$, modulation amplitude of $2 \mathrm{G}$. Thermogravimetry and differential thermal analysis (TG/DTA) curves were recorded with a Thermal Analyzer TA Instruments SDT Q600 V20.9 Build 20 on an interval $30-700^{\circ} \mathrm{C}$, at a heating rate of $10^{\circ} \mathrm{C} / \mathrm{min}$, in alumina crucibles and a dynamic air atmosphere.

\section{General synthesis of the metal complexes}

$\mathrm{Cu}(\mathrm{II}), \mathrm{Co}(\mathrm{II})$ and $\mathrm{Ni}(\mathrm{II})$ complexes of the ligand $\mathrm{L}$ were prepared by following a general method. The metal salt $\left[\mathrm{Cu}\left(\mathrm{NO}_{3}\right)_{2} \cdot 3 \mathrm{H}_{2} \mathrm{O}, \mathrm{Co}\left(\mathrm{NO}_{3}\right)_{2} \cdot 6 \mathrm{H}_{2} \mathrm{O}\right.$ or $\left.\mathrm{Ni}\left(\mathrm{NO}_{3}\right)_{2} \cdot 6 \mathrm{H}_{2} \mathrm{O}\right](1.24 \mathrm{mmol})$ was dissolved in $10 \mathrm{~mL}$ distilled water. To a solution of ligand (L) (2mmol) dissolved in $\mathrm{NaOH} 1 \mathrm{M}$ at $\mathrm{pH}=12$, was added slowly, dropwise, a solution of the metal salt, at room temperature. The mixture was stirred for $2 \mathrm{~h}$. By adding a solution of metal ions to a solution of ligand, 
immediate color change was observed depending on the metal ion. Also the $\mathrm{pH}$ was changed at 5.5-6.00 for the copper complex, 6.50-7.00 for the cobalt complex and 7.00-7.50 for the nickel complex. After standing overnight at room temperature, the resulted precipitates were vacuum filtrated and washed with distilled water and finally dried in air at room temperature.

\section{REFERENCES}

1. L. Lomozik, A. Wojciechowska, Monatshefte für Chemie, 1985, 116, 719.

2. I. Sakiyan, E. Loğoğlu, S. Arslan, N. Sari, N. Sakiyan, BioMetals, 2004, 17(2), 115.

3. A. Temitayo, O. Isaac, A. Olugbenga, International Journal of Chemistry, 2012, 4(2), 49.

4. A. Marcu, A. Stanila, D. Rusu, M. Rusu, O. Cozar, L. David, Journal of Optoelectronics and Advanced Materials, 2007, 9(3), 741.

5. G. Indira Devi, P. Smitha, International Research Journal of Biological Sciences, 2013, 2(6), 16.

6. L. Menabue, M. Saladini, Journal of Crystallographic and Spectroscopic Research, 1992, 22(6), 713.

7. K. Nishimura, X. Lu, R.B. Silverman, Journal of Medicinal Chemistry, 1993, $36,446$.

8. G. Byk, C. Gilon, Journal of Organic Chemistry, 1992, 57, 5687.

9. K. Yahagi, K. Tsujii, H. Hirota, Y. Matsumura, Eur. Pat. 0248294 A2, 1987.

10. M. Darabantu, C. Maiereanu, G. Plé, C. Berghian, E. Condamine, Y. Ramondenc, Heterocyclic Communications, 2001, 7(6), 593.

11. L. Zapala, M. Kosińska, E. Woźnicka, L. Byczyński, W. Zapala, Journal of Thermal Analysis and Calorimetry, 2016, 124, 363.

12. N.S. Al Radadi, S.M.A. Al Ashqar, M. M. Mostafa, Synthesis and Reactivity in Inorganic, Metal-Organic and NanoMetal Chemistry, 2011, 41(2), 203.

13. E. Prenesti, S. Berto, P.G. Daniele, Spectrochimica Acta Part A, 2003, 59, 201.

14. T. Stalin, N. Rajendiram, Journal of Photochemistry and Photobiology A: Chemistry, 2006, 182, 137.

15. F. Dimiza, S. Fountoulaki, A.N. Papadopoulos, C.A. Kontogiorgis, V. Tangoulis, C.P. Raptopolou, V. Psycharis, A. Terzis, D.P. Kessisoglou, G. Psomas, Dalton Transactions, 2011, 40, 8555.

16. K. Raha, P.S. Makashir, E.W. Kusian, Journal of Thermal Analysis and Calorimetry, 1989, 35, 1173. 
17. L. Ghizdavu, C. Bălan, L. David, C. Bâtiu, O. Cozar, D. Ristoiu, Journal of Thermal Analysis and Calorimetry, 2000, 62, 729.

18. L. David, C. Craciun, C. Bălan, O. Cozar, L. Ghizdavu, C. Bâtiu, Acta Chimica Slovenica, 2001, 48, 407.

19. F. Mabbs, D. Collisson, "Electron Paramagnetic Resonance of $d$ Transition Metal Compounds", Elsevier, Amsterdam, 1992, p.102. 